\title{
Opportunities that exist for communication experts in the field of communication consulting
}

Dale Eugene Shriver II

West Virginia University

Follow this and additional works at: https://researchrepository.wvu.edu/etd

\section{Recommended Citation}

Shriver, Dale Eugene II, "Opportunities that exist for communication experts in the field of communication consulting" (2000). Graduate Theses, Dissertations, and Problem Reports. 889.

https://researchrepository.wvu.edu/etd/889

This Thesis is protected by copyright and/or related rights. It has been brought to you by the The Research Repository @ WVU with permission from the rights-holder(s). You are free to use this Thesis in any way that is permitted by the copyright and related rights legislation that applies to your use. For other uses you must obtain permission from the rights-holder(s) directly, unless additional rights are indicated by a Creative Commons license in the record and/ or on the work itself. This Thesis has been accepted for inclusion in WVU Graduate Theses, Dissertations, and Problem Reports collection by an authorized administrator of The Research Repository @ WVU. For more information, please contact researchrepository@mail.wvu.edu. 


\title{
Opportunities that Exist for Communication Experts In the Field of Communication Consulting
}

\author{
Dale E. Shriver, II
}

\author{
Thesis submitted to the \\ Eberly College of Arts and Sciences \\ at West Virginia University \\ in partial fulfillment of the requirements \\ for the degree of \\ Master of Arts \\ in Communication Studies
}

James C. McCroskey, Ed.D., Chair

Matthew M. Martin, Ph.D.

Virginia P. Richmond, Ph.D.

Department of Communication Studies

\author{
Morgantown, West Virginia \\ 2000
}

Keywords: communication, consulting, graduate students,

Copyright 2000 Dale E. Shriver, II 


\section{ABSTRACT \\ Opportunities that Exist for Communication Experts in the Field of Communication Consulting}

\section{Dale E. Shriver, II}

This study examined the opportunities that exist for communication experts, particularly graduate students, in the field of consulting. Interviews were conducted with established consultants to determine how consultants describe their job functions, what kinds of consultants are needed in organizations, and what barriers to entry exist for those wishing to enter the field. Results indicate that there are several factors to consider when attempting to enter the field of consultation. 


\section{ACKNOWLEDGEMENTS}

This is dedicated to my father, Dale, and my stepmother, Ann. Without their words of encouragement and their push for me to pursue an academic career in communication studies, my life course would have gone a different direction. My deepest gratitude goes to both of them.

I would also like to express appreciation to the staff and faculty of the Communication studies Department at West Virginia University. Without their belief in me as a scholar, I could not have reached this point.

Words of gratitude are also in order for my master's class and the doctoral students in the department. I couldn't have accomplished all I have without their support. 


\section{TABLE OF CONTENTS}

\section{Chapter 1}

INTRODUCTION

Rationale

1

Research Questions

Chapter 2

METHODS

Participants and Procedures

Data Analysis

\section{Chapter 3}

RESULTS

$\begin{array}{ll}\text { Sample } & 12 \\ \text { Research Question One } & 13 \\ \text { Research Question Two } & 14 \\ \text { Research Question Three } & 19 \\ \text { Research Question Four } & 22\end{array}$

\section{Chapter 4}

DISCUSSION

Sample $\quad 26$

Research Question One 27

Research Question Two 30

Research Question Three 32

Research Question Four 34

Suggestions for Communication

Graduate Students 37

Summary 39

$\begin{array}{ll}\text { References } & 41\end{array}$

Appendix A

Interview Questions 43

Appendix B

Suggested Reading List 45

$\begin{array}{ll}\text { Table } 1 & 47\end{array}$

$\begin{array}{ll}\text { Table } 2 & 48\end{array}$

$\begin{array}{ll}\text { Table } 3 & 49\end{array}$ 


\section{Chapter One}

\section{Opportunities that Exist for Communication Experts \\ In the Field of Communication Consulting \\ RATIONALE}

There is a need for students of human communication studies to have an understanding of the opportunities that exist for them in the job market after their academic pursuits have come to a close. The field of communication studies is varied and diverse and often with that diversity comes a great deal of ambivalence and misunderstanding about potential career tracks. Many communication students may not fully know what great potential exists in their degrees. Both graduate and undergraduate students struggle with finding their niche in the marketplace and often fail to accurately describe their academic endeavors when placed under public scrutiny.

It becomes confusing for those students, especially undergraduates, to decide what career track to adopt once they graduate with a degree in communication studies. Unlike a degree in accounting, where the graduate will probably focus on becoming an accountant, or a degree in engineering where the student will probably focus efforts on constructing or improving products, the degree in communication studies will not offer such a focus. Undergraduates are often coached into the understanding that 
their degree is a "do-it-yourself" venture where the student focuses on specific interest areas where communicative competence is relevant.

As with undergraduates, the graduate student may be just as confused as to what to do with a newly earned higher level of education. Even after spending a year or more in graduate studies, the degree remains a "do-it-yourself" venture. To facilitate this, graduate students are often given options as to what they can study so that their individual needs are served.

In addition to the students being confused, the general population outside of the discipline questions the value of a degree in communication studies. This is probably due to a lack of understanding about what the degree entails and the lack of a concrete application of such a degree. For example, in a recent episode of the television show "The Simpson's," a comment made by the physician character, Dr. Julius Hibbert, to an injured football player, ridiculed the idea of holding a degree in communication studies:

Hibbert: (to the injured football player) "Oh, your playing days are over, my friend. But you can always fall back on your degree in...communications?! Oh dear lord!" (Gibby, $2000)$ 
This is just one humorous example of how the degree in communication studies is not fully understood by the popular culture. Lack of concreteness may be one of the reasons why this discipline is misunderstood. Due to this misunderstanding, graduates seeking employment are often queried about their endeavors during job interviews. A graduate might be asked during a job interview, "What does a communication student do? Work on telephones?" Many communication studies undergraduates might not be prepared to answer this question. Not only is the general populous confused about their chosen subject, but also students might not know how to verbalize what it is they study. In fact, communication studies majors, both at the graduate and undergraduate levels, are well suited to work in a variety of different fields. The field that a communication major chooses to work in varies depending on his or her interest. One concrete career option that may be persued by the communication major might be that of "communication expert" within a company, department, or unit. This type of position, as a communication expert, is the key focus of this research. These experts are often called upon to "fix" problems that arise among supervisors and subordinates, as well as customer relations issues. These types of employees are often called communication consultants and 
offer a concrete example of a career in which communication specialists are particularly well suited.

Many communication scholars might find working in an organization, or independently, as a consultant very rewarding. Consultants balance a variety of theoretical constructs, personal experiences, and practical applications within organizations. The field of consultation has been defined in a variety of different ways.

Dewine (1994) has defined consulting as, "entering into a system (or intervening) to stop the progression of some destructive human process and to improve the ability of the organization to function" (p.24). Blake and Mouton (1976) describe consultation as:

"...a useful tool in helping individuals deal with many of the complex difficulties they face today. Consultants offer assistance by intervening-that is, by taking some action to help a client solve his or her problem." (p.2)

Although these definitions vary slightly, they offer a tangible insight into the areas in which communication specialists can make application of the knowledge they have attained. This is especially true where communication constructs are the matter in question. For the purposes of this paper, a simplification of these definitions for a communication 
consultant can be defined as being a person who bridges the gap between theoretical human communication constructs and real-life applications to solve problems that arise around communication issues.

The field of consulting is a diverse field that could range from an accounting consultant to an industrial consultant to an engineering consultant. However, for the purposes outlined here, the focus will stay on the communication consultant, specifically those who deal with human communication issues. This paper examined the possibilities that exist for human communication specialists to enter the world of communication consulting as a career and attempt to discover the barriers that exist to enter the field. 


\section{RESEARCH QUESTIONS}

One of the first explorations that an aspiring consultant would need discover about careers in consultation, would be to locate some consultants with whom to develop a relationship. This could be considered the exploration period. Since, locating consultants was the first step, the first research question dealt with locating consultants:

RQ1: Who are communication consultants and how can they be located?

Once this research question was answered, it was logical to discover what types of job functions they perform. Since the consultant's position is highly varied, there was a wide variety in job descriptions. This called for a second research question: RQ2: How do communication consultants describe their job functions?

Graduate students and communication experts would gain insight into knowing what kinds of consultants are needed in organizations so that they can better market themselves. Since the career in consulting probably does not necessarily involve selling a concrete product, it was important to discover what kinds of services are needed in organizations. This lead to the third research question: 
RQ3: What kinds of communication consultants are needed in the dynamic workplace today?

Once the above three research questions were answered regarding locating consultants and learning about their job functions, it was important to know the barriers to career entry that exist. As with any organization, it is important to know what barriers exist for entry. This is the ultimate goal of anyone seeking entry to any field, and understanding this will make a stronger candidate for a position. This lead to the fourth and final research question:

RQ4: What barriers to entry exist for aspirants who wish to become consultants?

These research questions were answered by interviewing consultants who are established in the field. They have the insight that is needed for an aspiring consultant to enter the field and be successful. To answer these general research questions, systematic study was needed, using interview data. 


\section{Chapter Two}

\section{METHOD}

\section{PARTICIPANTS AND PROCEDURES}

To answer the research questions outlined, interviews were conducted with consultants who deal frequently with communication issues. Since the primary focus of this paper is on communication, consultants who do not deal with human communication issues were systematically excluded from the study. For example, accounting and engineering consultants were not interviewed.

In order to discover the sampling frame at hand, two methods were used. First, lists of consultants were obtained through pre-established relationships. In essence, one consultant contact led to another contact. There were questions at the end of each interview to see if there are other consultants who might be willing to be interviewed.

An Internet search for consultants also proved to be beneficial. The Internet has quickly become an easy way to promote entrepreneurs, and many people have discovered this. It is relatively inexpensive to put up a web page, and it gives relatively "free" advertising for many companies and individuals. Since many entrepreneurs are using the Internet, this study assumed that consultants are also doing this. Most of the 
consultants that were contacted used some form of advertising on the Internet.

There are some limitations involved in using a convenience sample of this type. Primarily, the information obtained through this study can not be assumed to be representative of all consultants because of the lack of a definitive sampling frame and lack of randomization. The information gathered from this study should be considered to be preliminary and would be beneficial to future research in the area. Perhaps once a definitive list of commonly held professional organizations becomes apparent, membership lists can be obtained. Random sampling may take place in the future.

Reliance on Internet sources systematically excluded those who do not use the Internet as a method of self-promotion. This was taken into consideration. Since, results here will be preliminary and are not intended to make sweeping generalizations, the results of this study were not impacted. Participants were offered "intrinsic" incentives to participate in the interview. They were told that this study is an attempt to define the field of communication consulting and to identify the opportunities that exist for communication specialists within the field. Therefore, by participating, the information they share about their own practices will help others 
learn about the field. As an added incentive, a copy of the final research report was mailed to the respondent if requested. These two incentives were adequate enough to draw interest in being interviewed.

When the interviews were conducted the participants were thanked for their participation and were asked if they would permit the recording of the interview. Recorded conversations were kept, so that pertinent information and quotations could be referenced when needed. All participants agreed to be recorded. Interview notes were taken during conversations and were used when answering the research questions. All participants were informed in advance of the true purposes of this study and no deception was used of any sort.

Appendix A contains the interview questions that were asked of participants. Since these questions are open ended, some deviation from order in which questions were asked occurred so that interviews could be more "conversational." All attempts were made so that this deviation was minimized so that the research would be as systematic as possible. Deviations from the question list were evident in the recordings and interview notes. DATA ANALYSIS

The information collected was summarized and synthesized to answer each research question. A careful examination of the 
recorded data assisted in collapsing the answers to the interview questions into categories. For example, when consultants were asked about their job functions, their responses were categorized so that some sort of generalization can be made. This data analysis was divided in such a way that all four research questions were answered, and to see if there were any areas left to be explored in the future.

The results section of this research project summarizes the categories of answers that were given by the interviewees. This information is organized by research question. A "suggested reading" list was also included as an additional tool for future researchers to use as a reference point (see Appendix B). 


\section{Chapter Three}

\section{RESULTS}

\section{SAMP LE RESULTS}

Ten participants, five males and five females, agreed to be interviewed. Each participant agreed to have the interview recorded. Years of consulting experience ranged from one to thirty-one years. The mean was 14.5 years experience. One individual had less than one year of experience, and was considered to be an outlier.

Each participant held some sort of college degree. Of the ten interviewees, all possessed a bachelor's degree, seven possessed a master's degree, and two held a Ph.D. or Ed. D. degree. Generalizing from the sample, it could be assumed that most consultants have pursued a significantly larger level of education beyond the Baccalaureate. It would be out of the ordinary to find a consultant with very little educational background. Most are extremely educated, with a noteworthy business background.

Focusing on bachelor's degrees, five of the interviewees held some sort of communication related degree. Specific focuses in degrees were bachelor degrees in organizational communication, interpersonal communication, speech communication, or mass communication. The other five in the sample held bachelor 
degrees in business administration, psychology, graphic design, and piano performance.

Half of the consultants interviewed held a master's degree in a communication studies field. The other two master's degree holding consultants attained them in organizational development, and in music performance. Of the three consultants who held doctorates, all were in communication studies. RESULTS OF RESEARCH OUESTION ONE

Research question one asked, "Who are communication consultants and how can they be located?" This question dealt primarily with the discovery of communication consultants. To answer this question, participants were asked about the professional organizations they are members of. See Table 1 for a breakdown of organizations.

The most common organization that was listed by the consultants interviewed was the American Society for Training and Development (ASTD). Nine of the consultants interviewed either were members of this organization or believed that it was worthy for consultants to be involved with. The ASTD is an organization that serves as a resource for consultants and trainers, which holds annual conventions, and which publishes considerable amounts of materials for consultants and trainers to use. 
Other top organizations that were mentioned included many of the human communication scholarly organizations. Although less likely to provide resources for use during training and consulting interventions, respondents cited their utility when networking, and staying current with the literature regarding communication studies in general. Some of these organizations included: The National Communication Association, the International Communication Association, The Eastern Communication Association, and the Western Communication Association.

Other organizations mentioned included local chambers of commerce and other human resource groups. These other organizations were groups that were much more helpful for individuals, and were more specific to the individual needs of specific consultants and firms.

RESULTS OF RESEARCH QUESTION TWO

Research question two asked, "How do communication consultants describe their jobs and career functions?" This question was more difficult to pinpoint, but a collapse of interview questions one and two provided a good foundation. Specifically, these questions focused on a description of job functions. 
After examination of the data, a general trend is evident. Although the field of consulting is one that is very diverse, some generalization can be made. Most of the consultants interviewed worked in different fields. Some reported working in higher education as a professor, some reported being selfemployed as owners of their own consulting firm, and one reported that she works for a larger consulting firm as an internal consultant.

Although there are differences in specifics, the position of consultant could be considered to be one of the helping professions. Similar to teachers, the consultant is, all cases of this examination, always working with other people to make organizational improvements. In some instances, the consultants may be working together to improve the way change is communicated in an organization. In other instances, the consultant may be a process practitioner, where intervention is necessary to make positive changes to the organization. In the broadest sense, three areas emerged that could encompass most of the functions described by the consultants in this sample. They are trainer, coach, and specialist. Specific breakdowns are available in Table 2 .

The first of the three areas of specific examination is that of trainer. These consultants are involved directly in the 
training of adult students in communication constructs, such as listening skills, conflict management, change management, and so on. Several consultants in this sample (Bittman, 2000; DeWine, 2000; Doyal, 2000; Mesiti,2000; Soskin, 2000) indicate that they are involved in some aspect of the delivery of materials in these areas. These individuals indicate that they themselves conduct seminars so individuals can learn these constructs. For example, Mesiti (2000) says this about her career as a trainer: "I do a lot of training with companies on topics such as developing marketing strategies, how to communicate...but my focus stays on their development needs. I create customized programs, and they range anywhere from how to communicate effectively, technical writing skills, to communication over the phone. We create communication and writing units as well as communication and presentational skills....so that if individuals are presenting proposals, sales ideas, whatever it might be, then we are able to help them to present themselves well." (Bittman, 2000)

Also falling into this category includes those who are concerned primarily with communicating change. Several of the consultants interviewed (Clarke, 2000; Doyal, 2000; Keener, 2000 \& Soskin, 2000) said that they are involved in the development of plans to deliver some sort of organizational change into the 
organization. As a general trend, organizational leaders are not experts in this area, and often call on outside experts to deliver messages to their employees.

The second category that emerged was that of coach. Those who report being a coach frequently work one-on-one with corporate leaders on a variety of issues. For example, one interviewee (Weiner, 2000) says that he coaches his clients by "offering advice and council to senior management on a variety of human communication issues." Here, rather than working more with the employees of an organization, there is a focus on working with senior executives. Coaching is more of an upper level management function where as training is more of a lower level management focus. Instead of working with the front lines on issues, it can be generalized that these consultants work behind the scenes with the people who actually make the major decisions. Helping to set the agenda was another important focus for coaches. Another consultant, (Clarke, 2000) reported that he is involved heavily with helping to set goals and agendas for his clients. Clarke offers very little help as to the technical side of issues, but as a generalist he is able to shape the direction of the organization, so that the organization can make changes that are positively related with the direction of the 
organization. Specifically, he says this about his career as an executive coach:

"We are a consulting company. We might go in - have an executive meeting with the senior executive team or retreat where we look carefully at the vision strategies. We then take those vision strategies and develop communication plans to be sure that those visions are communicated throughout the organization." (Clarke, 2000)

The third category of consultant that emerged was that of a specialist. A specialist can be defined as a consultant who is hired specifically to perform some sort of technical or specialist work. In this sample, one consultant (Barraclough, 2000) was requested to develop assessment tools for a government agency. He was the key planner in making assessments about employee satisfaction and communication patterns within the organization. Conducting needs assessments is a technical process. It involves the development of instruments and the technical capability of being able to analyze the data that is returned. Barraclough describes his experience as a consultant in the following way:

\footnotetext{
"The inital idea was to do a baseline survey and then an 18 month follow-up to see if they were making improvements....the organization I worked for was not
} 
familiar with survey design and execution, and so, and the employee there ended up calling the department where she had graduated, which happened to be where I was working at the time. That lead to the organization calling on me to complete the task, since I had experience in this area." (Barraclough, 2000)

\section{RESULTS OF RESEARCH QUESTION THREE}

Research question three asked, "What kinds of communication consultants are needed today in organizations." This question was asked because it is important to know the market for aspiring consultants so they know what areas in which to specialize.

Dewine (2000) offered one concise answer to this. She said that basic training in communications skills will always be needed in organizations. DeWine says that, "we will never just do away with basic communication skills. We will always need people who can help groups reach decisions, and interact effectively." In addition, DeWine believes that others also need to learn how to use technology correctly. She says that a focus on technology is important in today's organizations. Many corporate leaders do not understand the implications of it's use. According to DeWine, technological advances have had major impacts on organizational communication and human relationships. Therefore, as part of her work as a consultant, she has been 
successful when offering assistance regarding understanding technology and reminding organizations to have "human moments." Other consultants (see Clarke, 2000; Doyal, 2000; \& Keener, 2000 for specifics) have identified that change in organizations is ongoing and never-ending. Doyal (2000) says that, "it's our job to come in and explain to employees what's changing." Since this action is cyclical action, many organizations are always experiencing change.

Since change in organizations is generally not viewed positively by employees, consultants have capitalized on this opportunity. Of the consultants in this sample, $70 \%$ engage in some sort of change consulting where the focus is placed on communicating these changes to organizational members. All of the consultants who work to communicate change, agree that consultants who do this will have job security in organizations of today and tomorrow. Since many consultants have had hands on experiences with organizations who are experiencing changes, they are able to bring to the table some good amounts of information that other people might find helpful. Soskin (2000) highlights some of her experiences in organizations where change is ongoing: "A lot of clients are getting rid of their I.T. [information technology] departments as they exist, and transferring those people on, into say a company like EDC, 
who does IT support 24-7. Or they might be getting rid of their accounting department, and sending them over to Andersen or Price Waterhouse. A lot of people are getting rid of $\mathrm{HR}$ [human resource] functions all together outsourcing is key. The big trend today is to focus on what they call their 'core' business. So for example, if it's an oil company, they would want to focus on procurement or drilling - not accounting or managing human resources. There is a trend towards moving towards consulting firms, and my job here is to be sure that employees understand why this change is happening and how it will impact their lives." (Soskin, 2000)

As a general rule, those consultants in this sample have also found their niche in helping others to become more effective speakers, but it is significantly less prevalent than the functions described above. Although the notion of rhetorical studies is considered to be old news in some circles, there is still a need for it. In this study, several consultants identified that they still engage in teaching people how to effectively speak in public (Mosesian, 2000 \& Soskin, 2000) and how to project a positive image (Bittman, 2000). 


\section{RESULTS OF RESEARCH QUESTION FOUR}

Research question four asked, "What barriers to entry exist for new consultants to this field." The answer to this question comes from responses to questions three and four regarding entry to the field, as well as questions thirteen and fourteen regarding barriers to entry. These questions dealt with entry to the field as well as questions about personal interest and advice they would give someone who is considering becoming a consultant. See Table 3 for a collapsed listing of responses.

The most common response to this question revolved around issues of credibility. A majority of consultants who were interviewed questioned the credibility of someone who is just finishing their degree. They question the value of services offered by someone who has little business experience. DeWine (2000) offers this insight into the issue of credibility:

"It's very important that people who are just getting into it [the field of consulting] realize that you have to have some kind of credential that would make people ask you to work with them. That credential could be that you've worked in industry for ten or thirteen years and have established contacts as an organizational member. Or that credential could be that you have a Ph.D. and you've worked in academia for fifteen or twenty years and they can call on 
you... Because somewhere, that gives you some kind of credibility, because who's sue DeWine, unless I have some sort of credentials or experience. I have no reason to believe that she knows anymore about my needs than someone off the street."

Established networks and client bases have emerged as probably the most important tool used by consultants. The profession is network based and it is important that the person entering the field, have some personal contacts in their repertoire. Pre-established contacts serve as referral for others, and are helpful in establishing new clientele and business. Keener (2000) reiterates this in his interview: "Don't go out on your own until you've got a client base and you'll probably have to 'steal' them. Build a client base with another company, and there are a lot of companies out there claiming to do change management stuff - like Andersen. They've got the base - a huge client base - and they know how to market themselves, so if you get to work for one of those kinds of companies, keep clients in your hip pocket to take with you, if you go out on your own." (Keener, 2000)

One consultant (Weiner, 2000) mentioned that in a literal sense of "barrier to entry," there are virtually none. He notes 
that it is very easy to start a consulting firm especially since many people own home computers. All someone needs is publishing software, and they could produce their own marketing materials and business cards. The only remaining paperwork involves filing with the state so that the business is legitimate.

However, Weiner (2000) says that the barriers arise when one is trying to make a business successful. He identifies that one must be completely dedicated, and committed to making the organization a success. He also posits that it may take over seven years from the time a consulting firm is opened until it first turns a profit.

Other responses to this question circle around the differences between the professional world and the academic world. DeWine (2000) says that students must understand the difference between organizational and academic experience. Possession of a master's degree does not give credibility in an organization. It must be earned in other ways. Therefore, this reflects the notion of credibility as a main barrier. Soskin (2000) comments about this in her interview:

"I'm probably a good person to ask because it's only been a year since I started...It's important to know that it's a completely different world from academics - there is some overlap, so you don't want to forget everything you already 
know, but it's different and you really have to be able to step out of where you are and start all over again. I know that if you're anything like me, you felt like you've built a certain amount of credibility - you've got a couple of degrees...it means a little bit, but it doesn't mean that much. The applied world is so different - so its like starting over." (Soskin, 2000) 


\section{Chapter Four \\ DISCUSSION}

These general results from this survey begin to unearth important issues. From each research question, additional discussion is merited so graduate students have some sort of handle on what it takes to become a consultant. This discussion will work from the perspective from which an aspiring communication consultant would be working. This perspective assumes that the student has a master's degree in communication studies, and has little experience in organizations outside of the academy. This discussion should answer the question, "Where should the aspiring consultant start?"

The aspiring consultant can take the information that is gained from this literature and have a better understanding of what kind of requirements are necessary for consultants to enter the field. The information contained above in the results should give some good ideas to the student as to what opportunities exist in the field of consulting. This chapter will discuss the findings systematically, beginning with the sample demographics, and finishing with the final research question.

\section{DISCUSSION OF SAMPLE}

Of the consultants interviewed, the vast majority indicated that they have many years of experience in the field. With the 
average being 14.5 years of consulting experience, all indicated that they had been working in other professional areas before practicing as a consultant.

As evident in the results, organizational experience is one of the most important possessions for an aspiring consultant to have. It is important for students and experts to realize that experience in organizations, over virtually any other preparation, will better prepare them to enter the field as a consultant.

In general, this research was conducted with participants who were highly educated. It can be safe to assume by judging from this sample those who aspire to become consultants must be highly educated as well. With $70 \%$ of the consultants interviewed holding a master's degree, it would be safe to assume that those who are successful graduate students might be good candidates to pursue a career in consulting. DISCUSSION OF RESEARCH QUESTION ONE

Research question one asked, "Who are communication consultants and how can they be located?" Answers to this question were determined from the questions dealing with professional organizations. Since it was determined that this is a network-based occupation, it is important to associate with other consultants. 
If there were trends in associations, this would be a good starting point for someone who is interested in beginning a career in consulting to look to for some starting points. It would also be very beneficial for prospective consultants to apply for membership, and become involved with these organizations professionally.

The organizations listed in Table 1 are organizations that would be beneficial for graduate students to be familiar with. If the student is interested in the field of communication consulting they consider joining some, particularly the American Society for Training and Development (ASTD). As indicated in the results above, the ASTD was by far the most commonly mentioned organization. The majority of interviewees indicated that this was possibly the best organization to belong to because of their vast resources available for consultants, and because of excellent annual conventions.

The National Communication Association ranked second in frequency of mention. This is primarily an academic organization, and its ranking is probably a function of the sample. Most consultants that mentioned this organization said that it was strictly an academic organization, and it does very little in terms of providing professional resources. However, it 
has been used to network and keep current on communication research.

It would also be very beneficial for prospective consultants to apply for membership, and become involved with the other professional organizations that are mentioned in Table 1. Information could be shared between consultants, and trends in organizations could be identified. The importance of belonging to the local chamber of commerce also emerged. Respondents indicated that since this profession is heavily grounded in personal contacts, becoming a member of the chamber and being involved in local activities would be beneficial. Business partnerships can be established and a relationship with the municipality in which one is located can be cultivated.

Many of the members in the sample either are college/university instructors or had been in the past. Many of them taught human communication studies. An excellent place to locate consultants in a particular geographic area would be to call a nearby university and ask for referrals to communication consultants. Results indicate that secretaries have been helpful in providing these references.

This leads to a reoccurring theme within the field of consulting. The field is heavily reliant on establishing personal contacts as a marketing tool. In fact, many established 
consultants rely solely on word of mouth as a marketing tool. This was said to be one of the best marketing tools available. However, many of the consultants interviewed spent large amount of time and money on mass mailings early in their careers. They passed many hours trying to sell their services. However, once established, consultants tend to rely less on "marketing." Many have abandoned their marketing budgets, and use only business cards, as their single marketing tool. This may be a function of time spent in the field.

DISCUSSION OF RESEARCH QUESTION TWO

The second research question asked, "How do communication consultants describe their job functions?" To answer this question, the focus is put on three specific areas: training, coaching, and specialization. These three areas best summarize the findings from the results.

In order to be part of the training profession, it would be beneficial for graduate students who are interested in working in this area gain exposure to it. Actively working as an intern in a training firm, or participating in coordination of training sessions, would be a good beginning. Exposure to the actual work as a consultant can build networks, give valuable career experience, and provide references. Working with experienced 
veterans will help to equip an aspiring consultant with the tools needed to be successful.

It should also be kept in mind that if one is interested in working in a training field, they should have a firm background in pedagogy and androgogy. If one does not know the fundamentals of teaching and instruction, likelihood of success is minimal. Course work and classroom experience can be valuable to an aspiring consultant.

Coaching also emerged as one of the three major areas in which consultants work frequently. This is a one-on-one type situation where individuals work together to achieve some sort of common goal. Since this is more of an upper-level management type of activity, it is very important that these consultants have a firm grasp on how organizations work. They must also have strong interpersonal communication skills.

More often than not, the major requirement to become a coach is that the consultant have experience in organizations. It is highly unlikely that a chief executive office will call on a newly graduated college student to give him or her advice on a specific issue. It is more likely, however, that he or she will call upon someone that is more like them, and someone who has "been around the block" once or twice. This is evident in the interview data (Clarke, 2000 \& Keener, 2000). 
The third basic type of consultant was a specialist. In this instance, a specialist could be called in to perform some form of specialty work. This type of work is much more concrete. If someone were experienced in the analysis of data, he or she might be called in to make sense of the survey that was sent out by the organization's human resource department. In this instance, it would be most important for the consultant to simply have the experience in the area. Although this is still probably a heavily networked area, years of service is probably less important than the possession of the skills to complete the task at hand. Networks are important, but in terms of the specialist, the skills are more important.

\section{DISCUSSION OF RESEARCH QUESTION THREE}

Research question three asked, "What kinds of communication consultants are needed today in organizations?" This question was asked because it is important to know the market for aspiring consultants so they know what areas to specialize in.

For example, DeWine (2000) explained that organizations will always need people to teach others basic communication skills. This is because of the fact that not everyone can be experts in every area, and constant improvement can be made, even when the communicator is considered to be a good one. 
This is good news for the communication studies graduate student. If successful in their studies, communication students might secure a position conducting skills training workshops. Again, the key to this is gaining credibility as a trainer. This could be accomplished through establishment of personal contacts within the training and development circles or could be accomplished by working for a large firm in the training department. Students wishing to do this should focus efforts on gaining employment in large consulting firms such as Anderson Consulting, or Sheppard Associates.

Doyal (2000), Keener (2000), and Clarke (2000) all posited that change in organizations is inevitable. All organizations go through cycles of change, and since change in organizations is generally not looked upon favorably by employees, consultants are beneficial here.

This area is more difficult for graduate students to find a career in. Once again, many people who work with communicating change in organizations have had many years of experience in organizations, and would be hesitant to rely on a newly graduated student. People who have experienced organizational change first hand have a larger repertoire of information to share with people who have not experienced change on the same level. 
However, there are some limitations on relying on the information attained via self-report. When one is asked to justify his or her existence as an organizational member, he or she will do their best to be sure that they will continue to be needed. There is a self-serving bias in their response. The information that is presented by the consultants in this sample is self-serving in that they will always discuss the areas they specialize in. This is probably an example of the human instinct to survive. When asking a consultant, or any member of an organization, what types of jobs are needed, they will probably never advocate that their position be eliminated. Most responses that an interviewer would receive would at the very least justify existence in an organization, but would almost always take an extremely positive vantage point.

\section{DISCUSSION OF RESEARCH QUESTION FOUR}

Research question four asked, "What barriers to entry exist for new consultants to this field?" Responses to this question, as indicated in the results section, were varied. However, some general conclusions can be drawn from this research.

With the advent of home computers, it is very easy to start a home business. With a small amount of computer know-how, one can begin to build a business from the letterhead, to business 
cards, to other marketing materials. So, in the strictest sense of a "barrier," virtually none exist.

However, the difference exists in the fact that without business experience, a list of personal contacts, or a client list, it is very difficult to establish a successful business. Since the consulting business is highly geared towards the use of personal contacts to gain clients, marketing materials may not matter very much in the long run. It is much more important that one establishes a set of bridges within organizations.

Graduate students must examine the knowledge they gain in graduate school and always be looking for practical application for it. The definition that is posited at the beginning of this work theorizes that a consultant is someone that bridges the gap between theoretical application and real life application. If a student has the ability to take an academic construct and make a commercially viable product out of it, success can follow. Students should constantly scanning their courses for tidbits of information that they believe that someone else might be interested in buying one day. Weiner (2000) reinforced this idea during his interview:

"Although university is not a trade school, and the focus there is on teaching students 'how' to think, it should be open to making practical application of information...It 
wouldn't hurt - over a beer - for a professor to say to a student, 'here are some ways you might think about turning that academic article into something that a person who reads Fortune magazine might like to read." " (Weiner, 2000)

Graduate students would also benefit from working for a larger consultation firm before starting their own firm. Some of the respondents from this project indicated that these larger firms are more likely to hire those who are fresh out of graduate programs, and put them in a consulting type situation. Some examples of these might be Anderson Consulting, or Sheppard Associates. Once experience is gained in these organizations, and a professional repertoire of clientele is established, it might be more viable for those people to leave the comfort of a larger organization and venture out on their own.

Respondents indicate that it is very important that one gets involved in the business community in the area from which you are located. This will help to build a contact base, and to show to the community that one is serious about making improvements in local organizations. This will impact the overall success of the community at large.

In terms of barriers to entry and suggestions, one of the most valuable pieces of advice gained from this research was to 
not begin a career as a consultant. Since the word "consultant" indicates that someone has a level of expertise in some area of organizational life, it would be best if one gains real experience in organizations before he or she posits expertise. Although it may be tempting to begin a career as consultant, most college graduates would be hard pressed to find a consulting position directly out of college. SUGGESTIONS FOR COMMUNICATION GRADUATE STUDENTS:

Aside from gaining experience in organizations, the communication graduate student can begin preparation in college for a future career as a consultant. To achieve this, there are some tasks that a prospective graduate student should accomplish to be successful.

Graduate students should be enrolled in courses that will benefit them when leaving the academy. For example, students wishing to work in training and development should take some course work in organizational communication, organizational psychology, and human resources. These courses can give valuable organizational insight that a consultant would need to possess. The key is to take schema-building course work. As mentioned earlier, organizational experience is vital, but when coupled with course work, the information a consultant gives to an organization may be more stable. 
In addition to coursework, the graduate student may seek exposure to organizations through independent study credit, or through internships. This may be a good method for students to gain organizational experience, build networks, and make application of the traditional course work that was presented in class. It is most important that the student work in an area that he or she is interested. For example, if a student were to be interested in coaching, he or she may wish to couple together with an established coach, and negotiate the terms of an independent study or internship. Depending on time limitations, it may be beneficial for students to work in more than one organization, since a consultant must have a wide understanding of different types of organizations.

Graduate students should also become involved in the Association for Training and Development. If one is truly serious about working in the field of consulting, joining the ASTD is strongly recommended. According to the consultants interviewed, the ASTD has the best resources for those who are involved in training and coaching. Their conventions are well known for sharing information, establishing networks, and reinforcing skills.

Finally, the graduate student should consider becoming active in community projects in the geographic area in which they 
will be working. Once established in an area, the individual will benefit from working on community projects, economic development, and other pro bono work. This is vital for one to become established in the community as a leader and to establish the contacts that are necessary to thrive as a consultant. $\underline{\text { SUMMARY }}$

This study examined the opportunities that exist for communication studies students in the field of consulting. This was done so that the research questions posited could be answered.

Research question one asked, "Who are consultants, and how can they be located?" This question dealt primarily with the discovery of communication consultants. The most basic answer to this would be "within the ASTD." The ASTD was the most frequent answer to the interview questions regarding locating consultants. Research question two asked, "How do communication consultants describe their job and career functions?" It was discovered that the consultants in this sample described their careers as having a focus on training, coaching, or specialization. These three areas emerged as individual answers were collapsed into categories.

Research question three asked, "What kinds of communication consultants are needed today in organizations?" Two general 
answers became apparent. First, there is a need for trainers in organizations who specialize in human communication skills. Secondly, consultants who can assist with communicating organizational change will always be valued.

Research question four asked, "What barriers to entry exist for new consultants to this field." It was found that there are considerable occupational barriers that exist for new graduates who are hoping to enter the field of consulting. Lack of organizational experience and the need for networking emerged as the largest barriers. This study also outlines some future directions for graduate students, and emphasizes the need for the combination of organizational experience with academic work. Hopefully, this research will begin to shed more light on some aspects of communication consultation. This should give more options to both graduate and undergraduate students as how to conceptualize their education and the careers that are available. It also might work towards changing the public's notion that a degree in communication studies is one that has little practical application. Hopefully, scholars and employers will realize that a need for communication expertise is needed within organizations and that the education students work for will have practical utility in the workforce. 


\section{REFERENCES}

Barraclough, R. A. (Personal Interview). (2000). Interview Recording. (Cassette Recording).

Blake, R. R., \& Mouton, J. S. (1976). Consultation. Reading, MA: Addison-Wesley Publishing .

Bittman, N. (Telephone Interview). (2000). Interview Recording. (Cassette Recording).

Carnevale, A. P., Gainer, L. J., \& Meltzer, A. S. (1990). Workplace basics training manual. San Francisco: Jossey-Bass Publishers.

Clarke, B. (Telephone Interview). (2000). Interview Recording. (Cassette Recording).

DeWine, S. (Telephone Interview). (2000). Interview Recording. (Cassette Recording).

DeWine, S. (1994). The consultant's craft: Improving organizational communication. New York: St. Martin's Press.

Doyal, K. (Telephone Interview). (2000). Interview Recording. (Cassette Recording).

Gibby, C. [cgibby@byu.edu] (2000, February 08). Comm Major Comment/Faith off Episode (subject). [Newsgroup document]. URL news://alt.tv.simpsons.

Keener, J. (Telephone Interview). (2000). Interview Recording. (Cassette Recording). 
Mesiti, M. (Telephone Interview). (2000). Interview

Recording. (Cassette Recording).

Mosesian, K. (Telephone Interview). (2000). Interview Recording. (Cassette Recording).

Soskin, K. (Telephone Interview). (2000). Interview

Recording. (Cassette Recording).

Weiner, A. (Telephone Interview). (2000). Interview

Recording. (Cassette Recording) 
APPENDIX A

Interview Questions

I. Job Function

1. What do you do as a consultant?

2. If you had to write up a job description for yourself, what would the key elements be?

II. Interest/History

3. How did you become interested in consulting?/What sparked interest?

4. How long have you been in the field? What lead to your entry?

III. Firm/Clients

5. Do you own your own firm?/What company do you work for?

6. How many employees work for this company?

7. Who are your clients?

8. How do you recruit clients?

IV. Professional Membership

9. Do you belong to any professional organizations?

10. What professional organizations do you belong to?

11. How long have you been a member?

12. Are there other professional organizations that you may not belong to but believe to be noteworthy to the field?

V. Entry/Opportunities

13. What pieces of advice would you have for someone considering entry to this field?

14. What types of communication consultants are needed in organizations?

VI. Literature

15. What do you consider to be some of the best pieces of literature (both from the popular press and from

academia) out in circulation that deals with

consultation?

16. Which ones of these do you rely heavily upon?

VII. Contacts

17. Are there any other consultants you frequently work with on projects?

18. If yes, who are they and where are they located? 
VIII. Demographics

19. Sex of respondent

20. What is your age?

21. What degrees or certificates do you hold?

22. Where did you attain them? When? 
Appendix B

Suggested Reading List

\section{BOOKS :}

The 20\% Solution : Using Rapid Redesign to Create Tomorrow's Organizations Today by John J. Cotter

(November 1995) John Wiley \& Sons; ISBN: 0471132780

The 7 Habits of Highly Effective People : Powerful Lessons in Personal Change by Stephen R. Covey

(August 1990) Fireside; ISBN: 0671708635

Corporate Cultures: The Rites and Rituals of Corporate Life by Terrence E. Deal, Allan A. Kennedy

(May 2000) Perseus Books; ISBN: 0738203300

Consultants Craft : Improving Organizational Communication by Sue DeWine

(December 1993) Bedford Books; ISBN: 031206151X

Nuts! : Southwest Airlines' Crazy Recipe for Business and Personal Success by Kevin Freiberg, Jackie Freiberg, Tom Peters

(March 1998) Bantam Doubleday Dell Pub (Trd Pap); ISBN: 0767901843

When Giants Learn to Dance by Rosabeth Moss Kanter (July 1990) Touchstone Books; ISBN: 0671696254

Communicating Change : How to Win Employee Support for New Business Directions by Sandar Larkin (Contributor), T. J. Larkin

(April 1994) McGraw-Hill; ISBN: 0070364524

All I Really Need to Know I Learned from Watching Star Trek by Dave Marinaccio

(June 1994) Crown Pub; ISBN: 0517597985

If Aristotle Ran General Motors : The New Soul of Business by Thomas V. Morris,

(November 1998) Henry Holt \& Company, Inc.; ISBN: 0805052534

Leaders : Strategies for Taking Charge by Burt Nanus (Contributor), Warren G. Bennis

February 1997) Harperbusiness; ISBN: 0887308392

Leadership Secrets of Attila the Hun by Wess Roberts

(May 1991) Warner Books; ISBN: 0446391069

The Fifth Discipline: The Art and Practice of the Learning Organization by Peter M. Senge

(October 1994) Doubleday Books; ISBN: 0385260954 


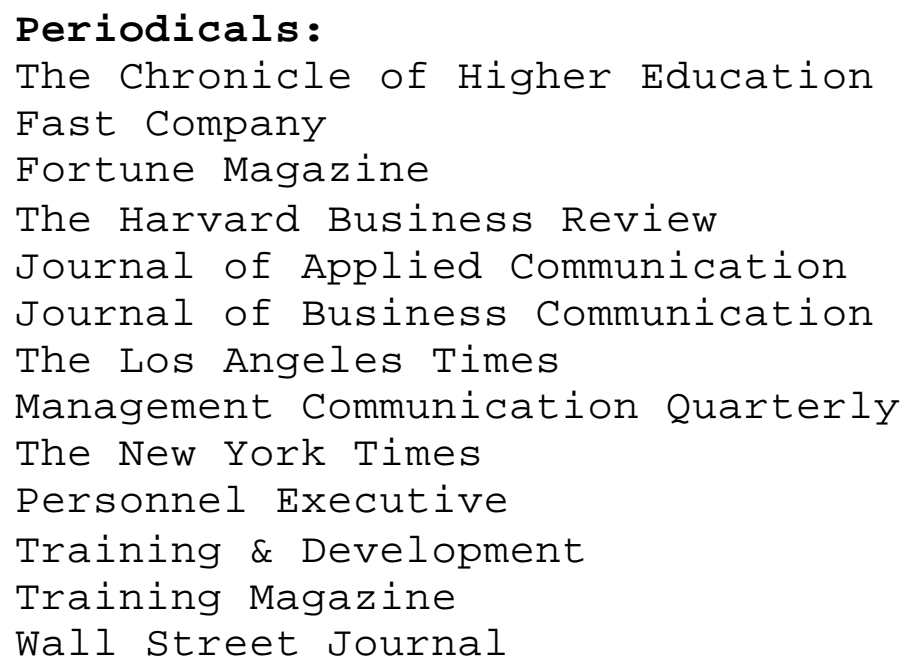


Table 1

Frequency of Professional Associations Mentioned

Collapsed Responses to Interview Questions 9 through 12

Professional Association $\quad$ Frequency

The American Society for Training and Development (ASTD)

Regional Communication Associations

Including: Eastern Communication Association,

Western Communication Association,

Southern Communication Association

\& Mid-Western Communication Association

The National Communication Association (NCA)

Chamber of Commerce Local Chapters

The International Association of Business

Communication (IABC) 2

The International Communication Association (ICA) 2

The Organizational Development Network 2

Coach University

University Associates (defunct)

Instructional systems Association

International Case Studies Organization

National Association of Women Business Owners

National Association of Female Executives

National Speakers Association

Public Relations Society of Australia

Society of Human Resources Management

United States Chamber of Commerce 
Table 2

Frequency of Job Functions Mentioned

Collapse of Interview Questions 1 and 2

Common Job Functions

Frequency

Communicating Change Management

6

Coaching and Leadership Communication

5

General Communication Training and Development

4

Strategic Planning

Marketing Communication

4

2

Less Common Job Functions

Frequency

Customer Service Training

Employee Communication

Image Management

Instructional Design

Process Specialization

Organizational Culture Issues

Public Speaking Training

Survey Specialist 
Table 3

Frequency of Barriers to Entry Mentioned

Collapse of Interview Questions 13 and 14

Barrier

Frequency

Credibility Issues

Few Barriers Exist

3

Long Time Until Established

3

Lack of Networks

2

Commitment Necessary

Difference Between Academia \& Professional Worlds

Marketing Problems 